Gut, 1984, 25, 47-51

\title{
Regulation of human gut B lymphocytes by T lymphocytes
}

\author{
R CLANCY, A CRIPPS, AND HEATHER CHIPCHASE \\ From the Department of Pathology, Faculty of Medicine, The University of Newcastle, Australia, and Hunter \\ Immunology Unit, Royal Newcastle Hospital, Newcastle, Australia
}

SUMmaRY The aims of this study were first, to assess whether or not immunoglobulin secretion from human gut mucosal B lymphocytes can be modified by $\mathrm{T}$ lymphocytes, and second whether human gut mucosal $\mathrm{T}$ lymphocytes are capable of regulating mucosal $\mathrm{B}$ lymphocyte function. $\mathrm{T}$ and $B$ lymphocyte enriched cell populations were isolated from gut mucosa and co-cultured in varying proportions. Addition of $T$ lymphocytes to $B$ enriched mucosal cell populations (ratio $\mathrm{B}: \mathrm{T}=2: 1$ ) showed that mucosal $\mathrm{B}$ lymphocytes were responsive to $\mathrm{T}$ cell 'help'. Addition of more $\mathrm{T}$ cells (ratio $\mathrm{B}: \mathrm{T}=2: 10$ ) suppressed immunoglobulin synthesis.

IgA is the predominant class of immunoglobulin synthesised in, and secreted from, human mucosa. ${ }^{1}$ Antibody secreted at mucosal sites regulates bacterial proliferation ${ }^{2}$ and antigen uptake, ${ }^{3}$ and thus itself must be finely tuned to local needs. Disturbed control of the local immune response may lead to a wide range of clinically relevant events such as excessive bacterial proliferation and the 'blind loop syndrome', ${ }^{4}$ excessive antigen absorption and immune complex formation, and autosensitisation. ${ }^{5}$ The level of control of the mucosal immune response has been little studied. Thus, while it is clear that B lymphocytes primed within Peyer's patches by absorbed antigen proliferate, ${ }^{6}$ differentiate, ${ }^{7}$ and migrate to various mucosal surfaces, ${ }^{8}$ the role of polyclonal mitogens and modulating $T$ lymphocytes within the mucosa in determining the rate of antibody secretion is unknown.

In this study, human gut mucosal B cells stimulated by the polyclonal mitogen, pokeweed mitogen (PWM), were co-cultured with T lymphocytes to examine first, whether B lymphocytes located within the gut mucosa can respond to $T$ lymphocyte mediated control, and second, whether mucosal $T$ lymphocytes can mediate help and suppression.

Address for correspondence: Professor R Clancy, Faculty of Medicine. The University of Newcastle, New South Wales, 2308, Australia.

Received for publication 21 March 1983.

\section{Methods}

MATERIALS

GUT MUCOSA

Gut was obtained from patients having stomach (eight), ileum (six), or colon (four) resection. Partial gastrectomy was for duodenal or gastric ulceration, resection of ileum was for Crohn's disease (two), Meckel's diverticulum (one) or carcinoma of the right side of the colon (three), and colectomy was for trauma (one) or colon carcinoma (three). Histological examination of the pyloric mucosa showed moderate chronic gastritis in each case. Ileum resected in association with the Meckel's diverticulum and the colonic carcinoma was histologically normal, while mild chronic inflammatory changes were detected in mucosa taken from macroscopically normal bowel resected in association with Crohn's disease, and histologically normal colon resected in association with colon carcinoma was used in these experiments.

\section{CELL ISOLATION, CHARACTERISATION AND SEPARATION}

A modification of several techniques has been developed, ${ }^{9} 10$ which provides $7 \times 10^{6}$ lymphocytes per gram of mucosa, with cell viabilities of greater than $95 \%$. Gut was washed in phosphate buffered saline within 30 minutes of resection, the mucosa dissected free from underlying tissue and cut into 1 $\mathrm{cm}^{2}$ pieces and incubated in $1 \mathrm{mM}$ DL-dithiothreitol 
(Sigma, USA) for 20 minutes at room temperature. The tissue pieces were then finely minced and incubated in clostridial collagenase $(25 \mathrm{U} / \mathrm{ml}$; CSL III, Worthington Biochem, USA) in RPMI 1640 for two hours at $37^{\circ} \mathrm{C}$ on an Adams Rotator in a humidified atmosphere with $5 \% \mathrm{CO}_{2}$ in air, using 10 $\mathrm{ml} / \mathrm{g}$ of tissue. The partly digested mucosa was then pressed through a stainless steel mesh (300 gauge) and the resulting cell suspension washed in $1 \mathrm{mM}$ DL-dithiothreitol (Sigma, USA) in RPMI 1640. Cell concentration in RPMI 1640 containing $100 \mathrm{IU} / \mathrm{ml}$ penicillin and $100 \mu \mathrm{g} / \mathrm{ml}$ streptomycin (Flow Lab, USA), $50 \mu \mathrm{g} / \mathrm{ml}$ gentamicin (Schering Corp, USA), $0.125 \mu \mathrm{g} / \mathrm{ml}$ Amphotericin B (Squibb, USA), and $50 \%$ heat inactivated fetal calf serum (GIBCO, USA), was adjusted to $1 \times 10^{7} / \mathrm{ml}$, added to an equal volume of carbonyl iron (Lymphocyte Separator Reagent, Technicon, USA), and incubated for 20 minutes at $37^{\circ} \mathrm{C}$. The cells were washed twice in RPMI 1640 , and resuspended at a concentration of $1 \times 10^{6} / \mathrm{ml}$ for microculture or $3 \times 10^{6} / \mathrm{ml}$ for surface marker studies.

$T$ cells were quantitated according to their capacity to bind to papain treated sheep erythrocytes $^{11}$ and $B$ cells quantitated according to the presence of surface immunoglobulin (sIg), using fluorescein conjugated $\mathrm{F}\left(\mathrm{ab}^{\prime}\right)_{2}$ rabbit anti-human IgG, IgA, and IgM (DAKO Immunoglobulin Ltd, Denmark). ${ }^{12}$

$T$ cell and $B$ cell enriched cell populations were prepared by double centrifugation of $\mathrm{E}$ rosetted lymphocytes over a Ficoll-Paque (Pharmacia Fine Chemicals, Sweden) gradient as previously described. ${ }^{13}$ Cells were washed three times and resuspended in supplemented RPMI 1640 at a concentration of $1 \times 10^{6} / \mathrm{ml}$. Mucosal T enriched cell populations contained less than $8 \% \mathrm{~B}$ cells, and mucosal B enriched cell populations contained less than $2 \% \mathrm{~T}$ cells.

\section{CELL CULTURE AND IMMUNOGLOBULIN}

ESTIMATION

Cell cultures were established in RPMI 1640 supplemented as above, with $10 \%$ heat inactivated fetal calf serum. Lymphocyte concentrations were $1 \times 10^{6} \%$ $\mathrm{ml}$, with a final volume of $0.2 \mathrm{ml}$ except for the T:B cell collaborative studies, when B cells were standardised at 100000 cells/culture, and $\mathrm{T}$ cells added at $\mathrm{T}: \mathrm{B}$ ratios of $1: 2$ or $10: 2$, as previously described to detect 'help' and 'suppression' respectively. ${ }^{13}$ Cultures were conducted in sterile microtitration plates with U-bottomed wells ('Nunclon', Nunc, Denmark), contained PWM (1/200 concentration, determined as 'optimal' from dose response curves: GIBCO, USA), and were incubated for seven days at $37^{\circ} \mathrm{C}$ in a humidified atmosphere with $5 \% \cdot \mathrm{CO}_{2}$ in air.

The concentrations of $\operatorname{IgA}$, IgG, and IgM in culture supernatants was measured by solid phase radioimmunoassay. ${ }^{14}$ Sensitivity of assay is for IgG $10 \mathrm{ng} / \mathrm{ml}, \mathrm{IgA} 20 \mathrm{ng} / \mathrm{ml}$, and IgM $60 \mathrm{ng} / \mathrm{ml}$.

\section{Results}

\section{CHARACTERISATION OF MUCOSAL CELL} POPULATIONS

Percentage of $\mathrm{T}$ cells obtained from pyloric mucosa $(72.8 \pm 2 \%)$ were greater than those obtained from colonic $(49 \cdot 4 \pm 6 \%)$ and ileal $(54 \cdot 6 \pm 12 \%)$ mucosa. B cells constituted $29 \pm 9 \%$ of intestinal mucosal cell preparations.

The spontaneous production of immunoglobulin from non-separated mucosal cell populations is seen in Table I. Polyclonal stimulation with optimal concentrations of PWM was found for IgA (4.0 fold increase), IgG ( 2.0 fold increase), and IgM ( 2.0 fold increase) with ileal mucosal cells. No increase in secretion rate for any isotype was seen with gastric mucosal cells.

RESPONSE OF MUCOSAL B LYMPHOCYTES TO T CELL 'HELP' (Table 2)

Little or no immunoglobulin was detected in cultures of 'enriched T cells'. Addition of mucosa T cells to autologous gastric mucosal 'B enriched' populations enhanced immunoglobulin secretion in: IgG, one of four studies; IgA, two of four studies; and IgM, nil of four studies. Depleting T lymphocytes from gastric mucosal cell preparations had no significant effect on immunoglobulin secretion. In 10 similar studies of intestinal B cell preparations, addition of $T$ cells $(B: T=2: 1)$ provided 'help' in three studies with IgG, eight studies with $\operatorname{IgA}$, and eight studies with IgM. Under these specified circumstances, $\mathrm{T}$ cell 'help' for IgM was greater than it was for IgG and IgA.

It should be noted that in all studies the three immunoglobulin isotypes were measured in the same supernatant and in each instance at least one immunoglobulin class was detected. Viability studies were routinely performed on terminated cultures using trypan blue exclusion. Viability fell in

Table 1 Spontaneous secretion of immunoglobulin from gut mucosal lymphocytes

\begin{tabular}{llcr}
\hline & $\begin{array}{l}\lg G \\
(\mathrm{ng} / \mathrm{ml})\end{array}$ & $\begin{array}{l}\text { IgA } \\
(\mathrm{ng} / \mathrm{ml})\end{array}$ & \multicolumn{1}{l}{$\begin{array}{l}\text { IgM } \\
(\mathrm{ng} / \mathrm{ml})\end{array}$} \\
\hline Stomach (5) & $53(0-265)$ & $380(0-950)$ & $88(0-440)$ \\
Ileum (7) & $73(0-250)$ & $32(0-235)$ & $247(0-630)$ \\
Colon (2) & $80(0-160)$ & $90(70-110)$ & $330(0-660)$ \\
\hline
\end{tabular}


Table 2 Mucosal B lymphocytes - response to T lymphocyte 'help'

\begin{tabular}{|c|c|c|c|c|c|c|c|}
\hline \multirow[b]{2}{*}{ Organ } & \multirow[b]{2}{*}{ Diagnosis } & \multicolumn{2}{|c|}{$\lg G(n g / m l)$} & \multicolumn{2}{|c|}{$\lg A(n g / m l)$} & \multicolumn{2}{|c|}{$\operatorname{IgM}(n g / m l)$} \\
\hline & & $B$ cells & $B: T(2: 1)$ & $B$ cells & $B: T(2: 1)$ & $B$ cells & $B: T(2: 1)$ \\
\hline \multirow[t]{4}{*}{ Colon } & Normal & 0 & 0 & 210 & 260 & 0 & 0 \\
\hline & Carcinoma of colon & 0 & 0 & 0 & 265 & 975 & 925 \\
\hline & Crohn's disease & 0 & 0 & 230 & 400 & 490 & 1190 \\
\hline & Carcinoma of colon & 0 & 77 & 410 & 1350 & 200 & 6750 \\
\hline \multirow[t]{6}{*}{ Ileum } & Carcinoma of colon & 75 & 980 & 0 & 250 & 0 & 1900 \\
\hline & Crohn's disease & 0 & 0 & 0 & 0 & 0 & 375 \\
\hline & Carcinoma of colon & 0 & 440 & 0 & 775 & 0 & 9500 \\
\hline & Crohn's disease & 0 & 0 & 0 & 0 & 350 & 1780 \\
\hline & Carcinoma of colon & 0 & 0 & 0 & 235 & 190 & 4000 \\
\hline & Meckel's diverticulum & 0 & 0 & 0 & 500 & 0 & 1200 \\
\hline \multirow[t]{4}{*}{ Stomach } & Duodenal ulcer & 135 & 105 & 1800 & 3150 & 370 & 0 \\
\hline & Duodenal ulcer & 0 & 0 & 375 & 430 & 230 & 0 \\
\hline & Duodenal ulcer & 0 & 85 & 230 & 162 & 205 & 205 \\
\hline & Gastric ulcer & 265 & 240 & 0 & 0 & 400 & 0 \\
\hline
\end{tabular}

both blood and mucosal lymphocyte cultures over the seven day period, with viabilities at day seven of $50-60 \%$ for blood lymphocytes and $25-30 \%$ for mucosal lymphocytes. Treating blood lymphocytes in an identical fashion to that used for mucosal lymphocyte separation had little effect on immunoglobulin secretion, but it did reduce their viability in terminated cultures by about $10 \%$.

Statistical analysis (Student's $t$ test) of data converted to percentage with maximum synthesis assigned as 100 , for individual isotypes, showed significant 'help' provided by T: B lymphocyte combinations, for IgA from colon B cells $(p<0.05)$, and for IgA $(p<0.05)$ and IgM $(p<0.05)$ from ileal B cells. Group analysis for different isotypes secreted from stomach B lymphocytes failed to demonstrate significant 'help'. If the colon and ileum data are pooled ('intestinal lymphocytes'), 'help' for both
$\operatorname{IgA}(\mathrm{p}<0.01)$ and $\operatorname{IgM}(\mathrm{p}<0.01)$ is significant.

RESPONSE OF MUCOSAL B CELLS TO T CELL SUPPRESSION (Table 3)

Controls for a 'crowding' effect, to account for suppression, were (1) addition of killed T lymphocytes to a final cell concentration of $4 \times 10^{6} / \mathrm{ml}$, and (2) quantitation of immunoglobulin in blood lymphocyte cultures, with concentrations up to $4 \times 10^{6} / \mathrm{ml}$. In each case, immunoglobulin concentration in supernatants correlated in a linear fashion with the B cell number.

Inhibition of immunoglobulin secretion from mucosal $B$ cells obtained from resected ileum by the addition of $T$ lymphocytes ( $\mathrm{B}: \mathrm{T}=2: 10$ ) was shown in nine out of the 10 studies where immunoglobulin secretion was detected at $B: T$ ratios of $2: 1$. Conversion of data converted to percentage with

Table 3 Mucosal B lymphocytes - response to T lymphocyte 'suppression'

\begin{tabular}{|c|c|c|c|c|c|c|c|}
\hline \multirow[b]{2}{*}{ Organ } & \multirow[b]{2}{*}{ Diagnosis } & \multicolumn{2}{|l|}{$I g G(n g / m l)$} & \multicolumn{2}{|l|}{$\lg A(n g / m l)$} & \multicolumn{2}{|l|}{$\operatorname{Ig} M(n g / m l)$} \\
\hline & & $B: T=2: 1$ & $B: T=2: 10$ & $B: T=2: 1$ & $B: T=2: 10$ & $B: T=2: 1$ & $B: T=2: 10$ \\
\hline \multirow[t]{4}{*}{ Ileum } & Carcinoma of colon* & 980 & 55 & 250 & 0 & 1900 & 0 \\
\hline & Crohn's disease ${ }^{*}$ & 0 & 0 & 0 & 0 & 375 & 410 \\
\hline & Carcinoma of colon* & 440 & 0 & 775 & 0 & 9500 & 270 \\
\hline & Crohn's disease ${ }^{*}$ & 0 & 0 & 500 & 235 & 1200 & 0 \\
\hline \multirow[t]{6}{*}{ Stomach } & Duodenal ulcer & 1170 & 270 & 1270 & 520 & 2150 & 150 \\
\hline & Duodenal ulcer & 540 & 550 & 7500 & 5800 & 340 & 185 \\
\hline & Gastric ulcer & 320 & 280 & 258 & 210 & 270 & 130 \\
\hline & Gastric ulcer & 240 & 280 & 0 & 0 & 0 & 410 \\
\hline & Duodenal ulcer* & 0 & 155 & 430 & 530 & 0 & 200 \\
\hline & Duodenal ulcer* & 85 & 175 & 162 & 177 & 205 & 0 \\
\hline
\end{tabular}

* Lymphocytes from sources used for 'help' experiments (Table 1). 
maximum synthesis assigned as 100 , showed significance only for IgM ( $\mathrm{p}<0.025)$, though pooling of data for all classes of immunoglobulin was significant $(p<0 \cdot 01)$. No such clear suppressive effect was seen with co-cultures of gastric mucosal $T$ and $B$ cells, as while suppression was noted in nine of the 18 studies, eight showed an increase of immunoglobulin secretion with the greater numbers of added $\mathrm{T}$ cells - that is, $\mathrm{B}: \mathrm{T}=2: 10$.

\section{Discussion}

$\operatorname{Ig} \mathrm{A}$ is the predominant gut immunoglobulin isotype determined by quantitation of class specific immunoglobulin containing cells, ${ }^{15}$ secretion from perfused gut, ${ }^{16}$ and assay of organ culture supernatants, ${ }^{17}$ and the trend seen with our limited data from analysis of supernatants of cultured mucosal lymphocytes separated from stomach and ileum, is consistent with these observations. Restricted studies suggest, however, that IgA may not always be the predominant immunoglobulin secreted from isolated mucosal lymphocytes ${ }^{10}$ and in the present study using intestinal $B$ cells in the reconstituted co-culture T cell 'help' experiments, we show that with low T:B cell ratios, IgM may predominate. Although this apparent paradox may be explained by differential cell survival in culture possibly influenced by the extraction procedure, the recent studies by Strober et al on T cell regulation of the gastrointestinal immune response suggest that these results may also reflect a culture induced change of control and 'switch' mechanisms normally mediated by a unique mucosal $\mathrm{T}$ cell population. ${ }^{18}$

Two observations are made in this study. First, the rate of immunoglobulin synthesis from human gut mucosal B lymphocytes is not fixed, and secretion is responsive to local control. Second, mucosal $\mathrm{T}$ lymphocytes provide a control mechanism through their capacity to both facilitate and suppress immunoglobulin secretion.

T cell 'help' was clearly seen in B cell preparations taken from intestine where enhanced immunoglobulin secretion was detected in two thirds of the experiments. 'Help' was most clearly observed with IgM. This is of interest in that IgA is the immunoglobulin which traditionally characterises the mucosal immune response, and IgM antibody synthesis is generally considered less ' $T$ cell dependent' than is antibody of other isotypes. ${ }^{19}$ It can be stated, however, that human mucosa does contain B lymphocytes capable of responding to local stimuli, and which retain a responsiveness to $T$ cell 'help'. The current study complements in vivo studies which indicate that local antigen stimulates relocated gut primed B cells. ${ }^{20}$ These observations have important implications with respect to the development of mucosal immunisation strategies in man.

Inhibition of immunoglobulin synthesis at higher $T: B$ cell ratios was regularly detected in cultures containing B cells from intestinal mucosa. High levels of suppression ( $>50 \%$ ) were found in all but one of nine studies of intestinal B cells. An imposed limitation on the expansion of B lymphocytes within the mucosa owing to a high level of sensitivity to $\mathrm{T}$ cell suppression, would allow for a stimulation of mucosal B cells in response to local needs, but only in a limited fashion, short of that degree of 'inflammation' that would cause pathology.

Gastric mucosal B:T cell co-cultures failed to show significant $T$ cell modulation of $B$ cell function, in the limited number of experiments available for analysis. The considerable variation in results may reflect shifts in the dose response curve not detected with the choice of ratios used, the variable infiltrate of lymphocytes found in all resected gastric mucosa, and the contamination of 'enriched' $T$ and $B$ cell populations which was greater with stomach mucosa than was found for intestinal cell populations. Real differences between mucosal $B$ cell responsiveness to $\mathrm{T}$ cell control at different levels of the gut may exist, however, and these remain to be analysed. Differences in luminal content and antigen handling may condition regional variations in $T-B$ cell relationships.

$\mathrm{T}$ cells are the dominant lymphocyte type within human gut mucosa ${ }^{21}$ and this is confirmed in our study. Effector functions have been described for human mucosal T cells. ${ }^{22}{ }^{23}$ Less is known regarding a regulatory role for mucosal $\mathrm{T}$ cells. Regulatory $\mathrm{T}$ cells have been identified in the mouse in relation to the afferent limb of the mucosal immune response ${ }^{24}$ and oral feeding is followed by the appearance of suppressor cells in Peyer's patches. ${ }^{25}$ Regulatory $T$ cells in the lamina propria limited the effector arm of mucosal immunity by inhibiting lymphocyte division after stimulation, ${ }^{26}$ and have been shown to enhance secretion of IgM from blood B cells. ${ }^{27}$ The current study extends these observations by showing that intestinal $\mathrm{T}$ cells inhibit immunoglobulin production from polyclonally activated mucosal B cells, as has been described for co-cultured blood lymphocytes. ${ }^{13}$

One previous study showed differences in spontaneous and PWM stimulated immunoglobulin secretion from cells isolated from normal and inflamed gut, ${ }^{28}$ using culture conditions differing significantly from those used here. In our study no attempt has been made to correlate findings with disease states. Future study of diseased mucosa may show defective T-B cell interaction within the 
lamina propria as contributing pathogenic mechanisms.

This work was supported by NH and MRC. We thank Drs E Hennessy and R Bissett for providing surgical specimens.

\section{References}

1 Tomasi TJ, Bienenstock J. Secretory immunoglobulins. In: Dixon FJ Jr, Kunkel $\mathrm{HG}$, eds. Advances in immunology vol 9. New York: Academic Press, 1968: 1 .

2 Gibbons RJ. Bacteril adherence to mucosal surfaces and its inhibition by secretory antibodies. In: Mestecky $\mathrm{J}$, Lawson A, eds. The immunoglobulin A system vol 45. New York: Plenum Press, 1974: 315.

3 Walker WA, Isselbacher KJ. Intestinal antibodies. $N$ Engl J Med 1977; 297: 767.

4 Brown WR, Butterfield D, Savage D, Tada T. Clinical, microbial and immunological studies in patients with immunoglobulin deficiencies and gastrointestinal disorders. Gut 1972; 13: 441.

5 Shorter RG. Immunological aspects of gastrointestinal disease: an up-to-date account of inflammatory diseases such as ulcerative colitis and Crohn's disease. In: Brent L, Holborrow J, eds. Progress in immunology II vol 4. North-Holland American Elsevier, 1974: 209.

6 Clancy R, Pucci A. Sensitisation of gut-associated lymphoid tissue during oral immunisation. Aust J Exp Biol 1978; 56: 337.

7 Craig SW, Cebra JJ. Peyer's patches: an enriched source of precursors for $\operatorname{IgA}$-producing immunocytes in the rabbit. $J$ Exp Med 1971; 134: 188.

8 Rudzig O, Clancy R, Perey DDR, Bienenstock J. Repopulation with IgA-containing cells of bronchial and intestinal lamina propria after transfer of homologous Peyer's patches and bronchial lymphocytes. J Immunol 1975; 114: 1599.

9 Clancy R. Isolation and kinetic characteristics of mucosal lymphocytes in Crohn's disease. Gastroenterology 1976; 70: 177.

10 Bull DM, Bookman MA. Isolation and functional characteristics of human intestinal mucosa lymphoid cells. J Clin Invest 1977; 59: 996.

11 Jondal M. SRBC rosette formation as a human T-lymphocyte marker. Scand J Immunol 1976; 5: 70.

12 Greaves M, Brown G. Purification of human T- and B-lymphocytes. J Immunol 1974; 112: 420.

13 Trent RJ, Clancy RL, Danis V, Basten A. Disordered immune homeostasis in chronic idiopathic thrombocytopenic purpura. Clin Exp Immunol 1981; 45 : 9.
14 Cripps AW, Virgin RJ, Lewins EG, Clancy RL. Radioimmunoassay of human IgG, IgA and IgM. $J$ Immunol Methods 1983; 57: 185-95.

15 Brandtzaeg P, Baklein K, Fauso O, Hoel PS. Immunohistochemical characterization of local immunoglobulin formation in ulcerative colitis. Gastroenterology 1974; 66: 1123 .

16 Bull DM, Bienenstock J, Tomosi T. Studies on human intestinal immunoglobulin A. Gastroenterology 1971; 60: 370.

17 Falchuk ZM, Strober W. Increased jejunal immunoglobulin synthesis in patients with non tropical sprue as measured by a solid phase immuno-absorptive technique. J Lab Clin Med 1972; 79: 1004.

18 Strober W, Rickman L, Elson C. The regulation of gastrointestinal immune responses. Immunology Today 1981: 156 .

19 Sinclair NR, Elliott EV. Neonatal thymectomy and the decrease in antigen sensitivity of the primary response and immunological memory systems. Immunology 1968; $15: 927$.

20 Husband AJ, Gowans JL. The origin and antigendependent distribution of $\operatorname{IgA}$-containing cells in the intestine. J Exp Med 1978; 148: 1146.

21 Goodacre R, Davison R, Singal D, Bienenstock J. Morphological and functional characteristics of human intestinal lymphoid cells. Gastroenterology 1979; 76: 300.

22 Kagnoff MF. Effects of antigen-feeding on intestinal and systemic immune responses. I. Priming of precursor cytotoxic $\mathrm{T}$ cells by antigen feeding. $J$ Immunol 1978; 120: 395.

23 Ferguson A, Jarrett EEE. Hypersensitivity reactions in the small intestine. I. Thymus dependence of experimental partial villus atrophy. Gut 1975; 16: 114.

24 Elson CO, Heck JA, Strober W. T-cell regulation of murine IgA synthesis. J Exp Med 1979; 149: 632.

25 Mattingly JA, Waksman BH. Immunologic suppression after oral administration of antigen. I. Specific suppressor cells formed in rat Peyer's patches after oral administration of sheep erythrocytes and their systemic migration. J Immunol 1978; 121: 1878.

26 Pucci-Favino A, Clancy R. Quantitative and functional aspects of T-cell populations in human gut mucosa. $L a$ Ricerca in Clinica e in Lagoratorio 1979; 9: 237.

27 Moretta L, Mingari MC, Moretta A. Human T cell subpopulations as normal and pathologic conditions. Immunol Rev 1979; 45: 163.

28 MacDermott $R$, Nash $G$, Bertovich $M$, Seiden $M$, Bragdon M, Beale M. Alterations of IgM, IgG and IgA synthesis and secretion by peripheral blood and intestinal mononuclear cells from patients with ulcerative colitis and Crohn's disease. Gastroenterology 1981; 81: 844. 